\title{
Evaluation of hematological, virologic and anthropometric parameters as progression markers in HIV-1 infected children
}

\author{
Inácio R. Carvalho, ${ }^{1}$ Jorge A. Pinto, ${ }^{2}$ Claudete A. A. Cardoso, ${ }^{3}$ \\ Talitah M. S. Candiani, ${ }^{4}$ Fabiana M. Kakehasi $^{5}$
}

\begin{abstract}
Objective: To analyze total lymphocyte count, total leukocyte count, hemoglobin levels, nutritional status, CD4+ T-lymphocyte count and viral load as markers of disease progression and/or death in HIV-infected children.

Methods: This retrospective cohort study assessed antiretroviral naïve HIV-infected children who were asymptomatic or had mild and/or moderate symptoms. The events of interest were: progression to clinical category C (according to the classification of the Centers for Disease Control and Prevention-CDC, 1994) or death. Values of total leukocyte count, total lymphocyte count, hemoglobin, weight-for-age z score, CD4+ T-lymphocyte count and plasma viral load obtained at admission were considered in the risk analysis of events of interest. The population was stratified into age groups: $<12, \geq 12$ to $<36, \geq 36$ to $<60$ months.
\end{abstract}

Results: One hundred and twenty patients, admitted between 1997 and 2003, met the inclusion criteria for the present study. The total median of follow-up duration was 7.4 months $(25-75 \%$ interquartile range $=3.8-21.1)$. In the multivariate analysis, only CD4+ T-lymphocytes count, according to the categories of the World Health Organization, and weight-for-age $z$ score $\leq-2$ were predictors of risk for disease progression in children older than 12 months. In children younger than 12 months, none of the variables was associated with risk of progression.

Conclusion: Nutritional status is an important aspect in the assessment of risk of disease progression in HIV-infected children older than 12 months.

J Pediatr (Rio J). 2009;85(2):149-156: HIV, children, weight/age, biomarkers, lymphocytes.

\section{Introduction}

The use of highly active antiretroviral therapy resulted in significant improvement of mortality, morbidity and quality of life indicators of children infected with human immunodeficiency virus type 1 (HIV-1). ${ }^{1-3}$ The decision of starting anti- retroviral therapy is based on clinical and laboratory parameters. ${ }^{4-7}$ Laboratory parameters, CD4+ T-lymphocytes count ( $C D 4+T L$ ) and plasma viral count of HIV, require sophisticated and expensive technology that is not easily available in developing countries. However, approximately $90 \%$ of the

1. Mestre, Saúde da Criança e do Adolescente, Departamento de Pediatria, Faculdade de Medicina, Universidade Federal de Minas Gerais (UFMG), Belo Horizonte, MG, Brazil. Membro, Grupo de HIV/AIDS Materno-Infantil, UFMG, Belo Horizonte, MG, Brazil. Médico preceptor, Residência em Pediatria, Fundação Hospitalar do Estado de Minas Gerais (FHEMIG), Belo Horizonte, MG, Brazil.

2. Doutor. Professor associado, Departamento de Pediatria, Faculdade de Medicina, UFMG, Belo Horizonte, MG, Brazil. Coordenador, Grupo de HIV/AIDS Materno-Infantil, UFMG, Belo Horizonte, MG, Brazil.

3. Doutora, Saúde da Criança e do Adolescente, Departamento de Pediatria, Faculdade de Medicina, UFMG, Belo Horizonte, MG, Brazil.

4. Mestre, Saúde da Criança e do Adolescente, Departamento de Pediatria, Faculdade de Medicina, UFMG, Belo Horizonte, MG, Brazil. Médica infectologista, FHEMIG, UFMG, Belo Horizonte, MG, Brazil.

5. Doutora, Saúde da Criança e do Adolescente, Departamento de Pediatria, Faculdade de Medicina, UFMG, Belo Horizonte, MG, Brazil. Membro, Grupo de HIV/AIDS Materno-Infantil, UFMG, Belo Horizonte, MG, Brazil.

No conflicts of interest declared concerning the publication of this article.

Suggested citation: Carvalho IR, Pinto JA, Cardoso CA, Candiani TM, Kakehasi FM. Evaluation of hematological, virologic and anthropometric parameters as progression markers in HIV-1 infected children. J Pediatr (Rio J). 2009;85(2):149-156.

Manuscript received Oct 14 2008, accepted for publication Jan 262009.

doi:10.2223/JPED. 1880 
individuals infected with HIV live in these countries. The World Health Organization (WHO) recommends starting the antiretroviral therapy at clinical stages 3 and 4 for all children older than 1 year in settings where laboratory tests are not available. $^{8}$

Inexpensive markers of progression derived from easily obtained parameters, such as blood test or nutritional assessment, can be useful for the follow-up of HIV-infected children living in regions where the access to more sophisticated laboratory methods is not available before the infection progression is clinically detectable. Due to the spread of the epidemic to the countryside in Brazil, such scenario can be found in Brazilian small towns distant from the reference centers and/or metropolitan areas. ${ }^{9}$

A meta-analysis of studies involving children evidenced that, for similar levels of plasma viral load and CD4+TL, the younger the child the higher the risk of disease progression or death. ${ }^{7}$ Therefore, the virologic and immunologic values to be considered as criterion for starting antiretroviral therapy vary according to age groups. A later analysis of the same population assessed the total lymphocyte count (TLC) as marker of risk for disease progression or death in 12 months and analyzed the validity of cutoff points used at the time for initiation of antiretroviral therapy. ${ }^{10}$ TLC was a good predictor of the risk of protection and/or death despite a weak correlation with CD4 ( $r=0.08-0.19)$, and the cutoff points initially recommended by the WHO in 2003 were not appropriate to assess the risk of disease progression. New cutoff points of TLC for four different age groups ( $<12$ months, 12 to 36 months, 36 to 60 months and $>60$ months) were then recommended for initiation of antiretroviral therapy. ${ }^{11}$ However, it is important to highlight that such parameters derived from a study involving children from developed countries.

The objective of the present study was to analyze the usefulness of TLC, total leukocyte count, hemoglobin levels, nutritional status (weight-for-age and height-for-age z scores), CD4+TL count and plasma viral load as markers of disease progression and/or death, defined as progression for category $\mathrm{C}$ of the Centers for Disease Control and Prevention CDC, 1994.

\section{Methods}

This is a retrospective cohort study conducted at the Center of Training and Reference in Infectious and Parasitic Diseases Orestes Diniz (Centro de Treinamento e Referência em Doenças Infecciosas e Parasitárias Orestes Diniz), in Belo Horizonte, state of Minas Gerais, Brazil. We included patients younger than 60 months, admitted to the service between July 1, 1997 and December 31, 2003, from which plasma viral load, CD4+TL and complete blood count (CBC) data previous to initiation of antiretroviral therapy was available.

Data were obtained from medical records and entered in a standardized questionnaire that included demographic and anthropometric data, results of laboratory tests (CBC, CD4, CD8 and plasma viral load) and clinical assessments. Clinical and laboratory assessments were performed every 3 or 4 months, and the information collected was reviewed and discussed by three pediatric infectologists before being entered in the database. The diagnosis of the diseases was standardized according to the clinical and laboratory criteria defined by the national program of STD/AIDS. ${ }^{12}$ Clinical and immunological classification met the criteria defined by the CDC. ${ }^{13}$ We used TLC and CD4+TL cutoff points in accordance with the definitions of the WHO. ${ }^{11}$ For plasma viral load cutoff points, we used the values recommended by the Paediatric European Network for Treatment of AIDS. ${ }^{14}$

CD4+ T-lymphocyte count (CD4) was performed using a flow cytometer (Facs Count, Becton Dickson ${ }^{\circledR}$ ). The quantification of plasma HIV-RNA was done using the nucleic acid sequence-based amplification, NASBA (Nuclisens Organon Teknica $\left.{ }^{\circledR}\right)$. CBC was performed using automated hematology analyzers (Cell Dyn 3000 and Cell Dyn 3500, Abbott ${ }^{\circledR}$ ). Weight and height were measured during each visit by the physician seeing the patient. Patients were weighed using weekly calibrated analytical scales, and their height or length was measured by means of length board and wall-mounted stadiometer. Weight-for-age and height-for-age z scores were calculated using the software for anthropometric calculations included in the Epi-Info version 6.4. ${ }^{15}$

Patients were classified as progressors or non-progressors according to the occurrence of events of interest (disease progression defined as clinical category C of the CDC, 1994, and/or death) and stratified into age groups (<12 months; $\geq$ 12 months to $<36$ months; and $\geq 36$ to $<60$ months). Only those measurements taken before the beginning of antiretroviral therapy were analyzed. In order to reduce possible bias, children who had the outcome (clinical progression or death) in the first 2 months after admission were excluded from the analysis. The univariate analysis of progression markers was performed considering the median of their values at admission. The time of patients' progression and/or survival was censored on the date of the last visit when there was loss to follow-up. Both groups were compared using the chi-square test or Fisher's exact test for categorical variables and non-parametric tests for continuous variables. The multivariate analysis used Cox's proportional hazard model, which considered hemoglobin levels and total leukocyte count as continuous variables, while TLC, \%CD4+TL, viral load and weight-for-age $z$ score were considered categorical variables. The statistical analyses were performed using the statistical packages SPSS (Statistical Package for the Social Sciences) version 12.0 and Epi-Info 6.4. This study was approved by the Research Ethics Committee of Universidade Federal de Minas Gerais (UFMG).

\section{Results}

Since our service was implemented, in 1989, until December 31 , 2003, 1,716 HIV-exposed children were seen, and 371 


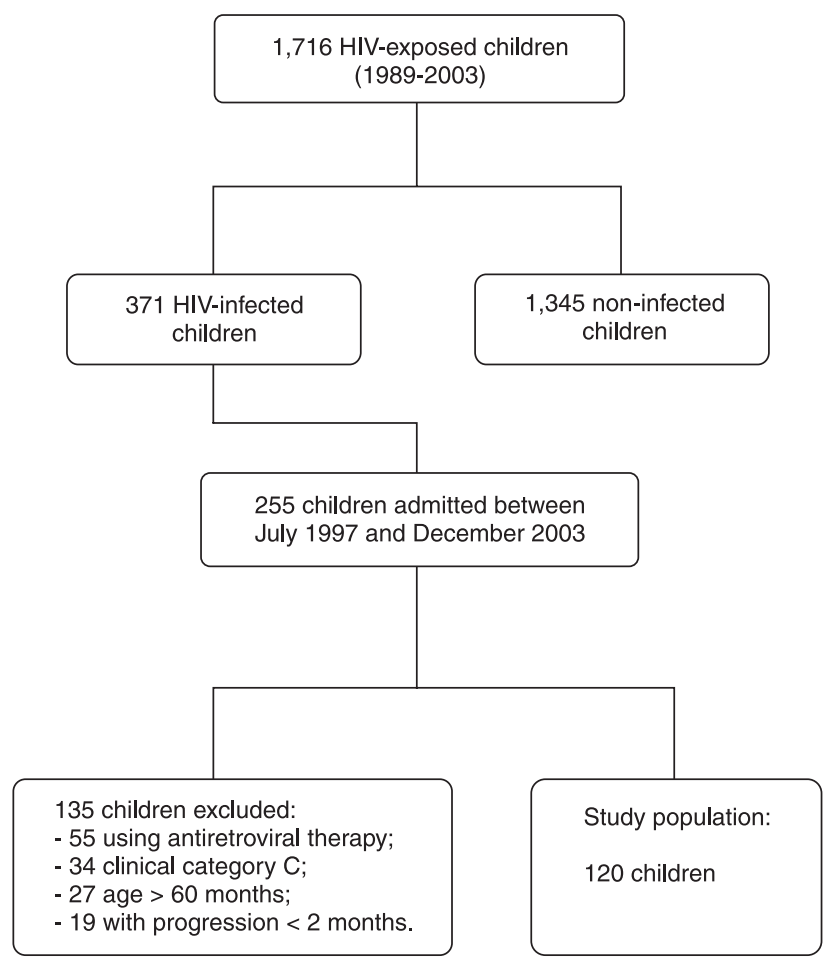

Figure 1 - Summary of the cohort selection process

of them had the diagnosis of infection confirmed. Between July 1997 and December 2003, 255 infected children were admitted. Figure 1 shows a summary of the population selection process for this study. We excluded 135 children: 55 were using antiretroviral therapy at admission, 34 were classified at clinical category C (CDC, 1994) at admission, 27 were older than 60 months, and 19 had clinical progression during the first 2 months of follow-up. Therefore, the group consisted of 120 children. There were no deaths, loss to follow-up or transfer to other services.

Total median of follow-up duration was 7.4 months, $25-75 \%$ interquartile range $(25-75$ IQR $)=3 \cdot 8-21.1$. Between progressors and non-progressors, the median of follow-up duration was 5.1 (25-75 IQR = 3.5-9.9) and 29.5 months (25-75 IQR = 9.5-52.0), respectively. The age group $<12$ months included the larger number of patients (41.7\%), and approximately half of them were male. The median of age at admission was 18 months (25-75 IQR $=4.8-36.2)$, and almost all patients had been exposed to vertical transmission. Demographic and clinical characteristics at admission are shown in Table 1.

The median of values for markers TLC, CD4+TL, hemoglobin level, plasma viral load and weight-for-age and height-for-age $z$ scores $\leq-2$ were compared between patient with and without progression of infection in the univariate analysis (Table 2). Absolute values of CD4+TL were significantly lower among progressors in the younger age groups
( $<12$ and $\geq 12$ to $<36$ months). Relative values of CD4+TL were significantly lower among progressors in the age groups $\geq 12$ to $<36$ months and $\geq 36$ to $<60$ months. In all age groups, progressors had significantly lower weight-for-age and height-for-age $z$ scores. Median of hemoglobin was significantly lower among progressors in the age groups $\geq 12$ to $<36$ months and $\geq 36$ to $<60$ months. Median of plasma viral load was significantly higher only among progressors of age group $\geq 36$ to $<60$ months. There was no significant difference between the groups of progressors and non-progressors for the other markers (TLC and total leukocyte count) in the age groups assessed.

For analysis of independent factors, we used the multivariate analysis (Table 3 ) including the following variables: hemoglobin level, total leukocyte count, weight-for-age z score $\leq$ $-2, \% C D 4+T L$ and plasma viral load. In the age group $<12$ months, none of the parameters assessed proved to be useful to differentiate progressors from non-progressors. However, in the older age groups ( $\geq 12$ to $<36$ months and $\geq 36$ to $<60$ months) the percentage values of $C D 4+T L$, classified according to the $\mathrm{WHO}$, and the weight-for-age $\mathrm{z}$ score $\leq-2$ were good predictors of risk for progression.

\section{Discussion}

Brazil offers a health care program for HIV carriers that is considered one of the best in the world. ${ }^{16}$ However, the usual lab tests used as disease markers, CD4+ T-lymphocyte count and plasma viral load, require sophisticated and expensive technology. Within a context of limited financial resources, both in distant regions of Brazil or other countries where there is no sophisticated laboratory infrastructure, the markers obtained by means of simple blood test and assessment of nutritional status can be useful tools to define the therapeutic management of HIV-infected children.

The present study has limitations inherent to the retrospective method. However, it is important to highlight that clinical and laboratory data were obtained from standardized medical records, reducing the information biases. With the purpose of reducing the biases inherent to a retrospective study, all clinical records were reviewed and discussed by three pediatric infectologists, using standardized criteria for the definitions of patients' clinical status. The present study did not have follow-up loss, an important limitation for longitudinal studies. Patients with clinical or immunological disease were excluded because the inclusion of these patients would not help to achieve the findings for the conclusion of the study. Therefore, patients who were admitted at the service using antiretroviral therapy also were excluded because the criterion of treatment initiation could not be clearly established or the exams done before the beginning of the antiretroviral therapy could not be available.

Usually, blood samples for exams of plasma viral load, CD4 and $\mathrm{CBC}$ were collected always at the same time, between 7 
Table 1 - Demographic and clinical characteristics of patients at admission between July 1, 1997 and December 31, 2003 ( $n=120$ )

\begin{tabular}{|c|c|}
\hline Characteristics & Cohort, n (\%) \\
\hline Male & $61(50.8)$ \\
\hline \multicolumn{2}{|l|}{ Age group categories } \\
\hline$<12$ months & $50(41.7)$ \\
\hline$\geq 12$ to 36 months & $42(35)$ \\
\hline$\geq 36$ to 60 months & $28(23.3)$ \\
\hline \multicolumn{2}{|c|}{ Median of age (25-75 IQR) } \\
\hline$<12$ months & $2.2(1.0-5.9)$ \\
\hline$\geq 12<36$ months & $22.6(18.8-28.0)$ \\
\hline$\geq 36<60$ months & $47.8(40.4-52.9)$ \\
\hline \multicolumn{2}{|l|}{ Route of infection } \\
\hline Vertical & $116(96.7)$ \\
\hline Breastfeeding & $1(0.8)$ \\
\hline Unknown & $3(2.5)$ \\
\hline \multicolumn{2}{|l|}{1994 CDC classification } \\
\hline $\mathrm{N}$ & $48(40)$ \\
\hline N1 & $27(22.5)$ \\
\hline N2 & $17(14.2)$ \\
\hline N3 & $04(3.3)$ \\
\hline A & $36(30)$ \\
\hline $\mathrm{A} 1$ & $12(10.0)$ \\
\hline $\mathrm{A} 2$ & $17(14.2)$ \\
\hline A3 & $07(5.8)$ \\
\hline B & $36(30)$ \\
\hline B1 & $10(8.3)$ \\
\hline B2 & $11(9.2)$ \\
\hline B3 & $15(12.5)$ \\
\hline
\end{tabular}

$\mathrm{A}=$ mild symptoms; $\mathrm{B}=$ moderate symptoms; $\mathrm{CDC}=$ Center for Diseases Control and Prevention; $25-75 \mathrm{IQR}=25-75 \%$ interquartile range; $\mathrm{N}=$ asymptomatic.

and 10 a.m., avoiding the well-known variations of these exams throughout the day. However, such exams are previously scheduled every 3 or 4 months and, therefore, sometimes children undergo the lab tests while they are suffering from acute bacterial or viral diseases. Commonly, patients are advised to be immunized 1 month before or on the same day the exams are performed, after blood collection.

Anthropometry allows for a diagnosis of malnutrition at early stages. Patients' height and weight were measured by the physicians seeing the patients using length board and wall-mounted stadiometer and weekly calibrated scales, which reduced the possibility of mistakes. In addition, loss of data was very low since we only missed one patient's weight and five patients' height.
The nutritional status, assessed using weight-for-age $\mathrm{z}$ score, was a sensitive predictor of risk for disease progression in children older than 12 months. A study conducted in Ruanda showed lower mean of weight-for-age z score among infected children when compared to those exposed to the virus but not infected at the third month of life. ${ }^{17}$ Similar findings were found in a Brazilian study before the era of highly active antiretroviral therapy. ${ }^{18}$ Initially, an American study evidenced decrease from 1 to 0.75 in the mean of weight-for-age z score during the whole follow-up period among HIV-infected children, but there was no significant statistical difference when compared to the HIV-exposed but uninfected children. ${ }^{19}$ Nevertheless, an elegant American prospective study ${ }^{20}$ demonstrated later that weight and height are significantly lower among HIV-infected children when compared to those values obtained from non-infected children belonging 
Table 2 - Median values for laboratory and nutritional markers at admission according to the disease progression in the age groups $(n=120)$

\begin{tabular}{|c|c|c|c|}
\hline \multirow[b]{2}{*}{ Variables by age group } & \multicolumn{2}{|c|}{ Median of values (25-75 IQR) } & \multirow[b]{2}{*}{$\mathbf{p}$} \\
\hline & Progressors & Non-progressors & \\
\hline \multicolumn{4}{|l|}{ TLC (cells/mL) 25-75 IQR } \\
\hline$<12$ months & $6,549(3,850-9,146)$ & $7,034(5,835-9,803)$ & 0.349 \\
\hline$\geq 12<36$ months & $5,184(4,145-7,853)$ & $4,610(3,090-5,300)$ & 0.142 \\
\hline$\geq 36<60$ months & $3,369(1,995-4,630)$ & $3,483(2,900-3,982)$ & 0.942 \\
\hline \multicolumn{4}{|c|}{ Total leukocyte count (cells/mL) } \\
\hline$<12$ months & $10,150(7,850-14,600)$ & $10,800(9,375-15,125)$ & 0.409 \\
\hline$\geq 12<36$ months & $10,300(8,100-13,000)$ & $9,280(7,700-11,800)$ & 0.424 \\
\hline$\geq 36<60$ months & $6,900(5,140-9,570)$ & $7,470(6,075-5,665)$ & 0.961 \\
\hline \multicolumn{4}{|l|}{ Hemoglobin (g/dL) 25-75 IQR } \\
\hline$<12$ months & $9.65(8.8-10.5)$ & $10.20(8.8-11.2)$ & 0.435 \\
\hline$\geq 12<36$ months & $10.1(8.5-10.9)$ & $12.2(10.2-12.6)$ & 0.023 \\
\hline$\geq 36<60$ months & $11.3(9.4-11.9)$ & $12.0(11.2-12.5)$ & 0.021 \\
\hline \multicolumn{4}{|l|}{$\begin{array}{l}\text { Plasma viral load }\left(\log _{10}\right) \\
25-75 \text { IQR }\end{array}$} \\
\hline$>12$ months & $5.70(5.1-6.1)$ & $5.25(4.6-5.9)$ & 0.21 \\
\hline$\geq 12<36$ months & $5.21(4.8-5.7)$ & $4.74(4.4-5.6)$ & 0.094 \\
\hline$\geq 36<60$ months & $5.39(4.9-5.9)$ & $4.65(4.2-4.9)$ & 0.019 \\
\hline \multicolumn{4}{|l|}{ CD4 (cells/mL) 25-75 IQR } \\
\hline$>12$ months & $1,600(947-2,210)$ & $2,696(1,992-3,610)$ & 0.02 \\
\hline$\geq 12<36$ months & $988(802-1,528)$ & $1,209(1,085-1,841)$ & 0.031 \\
\hline$\leq 36<60$ months & $525(166-1,001)$ & $853(707-1,086)$ & 0.062 \\
\hline \multicolumn{4}{|l|}{ CD4 (\%) 25-75 IQR } \\
\hline$>12$ months & $24.9(20.3-33.4)$ & $39.4(21.7-46.7)$ & 0.063 \\
\hline$\geq 12<36$ months & $19.2(16-23.3)$ & $29.5(26.3-42.2)$ & 0.001 \\
\hline$\geq 36<60$ months & $14.7(7.1-28.3)$ & $28.5(23.9-33.7)$ & 0.012 \\
\hline \multicolumn{2}{|l|}{ 25-75 IQR } & Weight-for-age z score & \\
\hline$>12$ months & $-1.22(-2.3-0.3)$ & $0.21(-1.4-1.2)$ & 0.027 \\
\hline$\geq 12<36$ months & $-1.19(-2.3-0.5)$ & $-0.16(-1.9-0.7)$ & 0.004 \\
\hline$\geq 36<60$ months & $-1.26(-2.1-0.6)$ & $-0.025(-1.3-0.7)$ & 0.029 \\
\hline \multicolumn{4}{|l|}{ Height-for-age z score } \\
\hline$>12$ months & $-1.48(-2.9-0.7)$ & $0.75(-2.1-0.8)$ & 0.051 \\
\hline$\geq 12<36$ months & $-1.78(-2.4-0.9)$ & $-0.28(-1.0-0.4)$ & 0.004 \\
\hline$\geq 36<60$ months & $-1.68(-1.9-1.0)$ & $-0.005(-1.5-0.7)$ & 0.012 \\
\hline
\end{tabular}

TLC = total lymphocyte count; $25-75 \mathrm{IQR}=25-75 \%$ interquartile range.

to the same socioeconomic status at 6 months of life. Such difference was correlated with the use of illicit drugs by the mother during pregnancy and other signs of AIDS-defining disease (pneumonia episodes, CD4 T-lymphocyte count and 
Table 3 - Results of Cox's proportional hazard models according to age groups

\begin{tabular}{|c|c|c|c|}
\hline Variable & $\mathbf{R R}$ & $95 \% \mathrm{CI}$ & $\mathbf{p}$ \\
\hline \multicolumn{4}{|l|}{ Age $<12$ months $(n=50)$} \\
\hline Hemoglobin & 0.87 & $0.66-1.14$ & 0.31 \\
\hline Total leukocyte count & 1.00 & $0.99-1.00$ & 0.73 \\
\hline $\begin{array}{l}\text { Total lymphocyte count } \leq \\
4,000 \text { cells } / \mathrm{mL}\end{array}$ & 2.44 & $0.80-7.14$ & 0.11 \\
\hline Weight-for-age $\mathrm{z}$ score $\leq-2$ & 2.13 & $0.72-6.25$ & 0.17 \\
\hline $\begin{array}{l}\text { CD4+ T-lymphocyte count } \leq \\
25 \%\end{array}$ & 2.17 & $0.97-4.76$ & 0.06 \\
\hline $\begin{array}{l}\text { Viral count } \geq 6.0 \log _{10} \text { or } \\
1,000,000 \text { copies } / \mathrm{mL}\end{array}$ & 1.53 & $0.67-3.57$ & 0.31 \\
\hline \multicolumn{4}{|l|}{$\begin{array}{l}\text { Age } \geq 12 \text { months to } 36 \text { months } \\
\quad(n=42)\end{array}$} \\
\hline Hemoglobin & 1.07 & $0.80-1.44$ & 0.62 \\
\hline Total leukocyte count & 1.00 & $0.99-1.00$ & 0.52 \\
\hline $\begin{array}{l}\text { Total lymphocyte count } \leq \\
3,000 \text { cells } / \mathrm{mL}\end{array}$ & 0.10 & $0.01-1.39$ & 0.09 \\
\hline Weight-for-age $z$ score $\leq-2$ & 3.70 & $1.12-12.5$ & 0.03 \\
\hline $\begin{array}{l}\text { CD4+ T-lymphocyte count } \leq \\
20 \%\end{array}$ & 6.25 & $1.72-25.0$ & $<0.01$ \\
\hline $\begin{array}{l}\text { Viral load } \geq 5.4 \log _{10} \text { or } \\
250,000 \text { copies } / \mathrm{mL}\end{array}$ & 1.16 & $0.37-3.70$ & 0.79 \\
\hline \multicolumn{4}{|l|}{$\begin{array}{l}\text { Age } \geq 36 \text { months to } 60 \text { months } \\
\qquad(n=28)\end{array}$} \\
\hline Hemoglobin & 1.16 & $0.68-2.00$ & 0.59 \\
\hline Total leukocyte count & 1.00 & $1.00-1.00$ & 0.54 \\
\hline $\begin{array}{l}\text { Total lymphocyte count } \\
(2,500 \text { cells } / \mathrm{mL})\end{array}$ & 1.69 & $0.27-10.27$ & 0.57 \\
\hline Weight-for-age $\mathrm{z}$ score $\leq-2$ & 5.36 & $1.09-26.47$ & 0.04 \\
\hline $\begin{array}{l}\text { CD4+ T-lymphocyte count } \\
(25 \%)\end{array}$ & 1.21 & $0.32-4.54$ & 0.77 \\
\hline $\begin{array}{l}\text { Viral load }\left(5.4 \log _{10} \text { or }\right. \\
250,000 \text { copies } / \mathrm{mL} \text { ) }\end{array}$ & 0.76 & $0.27-2.15$ & 0.60 \\
\hline
\end{tabular}

$\mathrm{RR}=$ relative risk $; 95 \% \mathrm{CI}=95 \%$ confidence interval.

use of antiretroviral therapy), which can potentially interact with the response variable. Unfortunately, the present study did not measure the influence of maternal factors together with anthropometric parameters as predictors of disease progression like other studies. ${ }^{20-22}$

Among the parameters derived from the $\mathrm{CBC}$ (total leukocyte count, TLC and hemoglobin level), only hemoglobin level at admission was useful to differentiate progressors from non-progressors in children older than 12 months. In the multivariate analysis, none of these parameters proved to be useful to predict risk of progression. The correlation between TLC and infection progression still remains controversial. ${ }^{10,23,24}$
The correlation between alternative markers and probability of death in 12 months was assessed in a study involving the U.S. population, showing TLC and albumin value as independent predictors of mortality and absence of association for the other parameters, such as hematocrit and total leukocyte count. ${ }^{23} \mathrm{~A}$ meta-analysis carried out in the United States and Europe detected the association between values of TLC in the beginning of the antiretroviral therapy and compared these values with the CD4 count. ${ }^{10}$ TLC was a good predictor of risk for progression or death in children older than 2 years. It had a less significant effect on younger children. However, a meta-analysis derived from longitudinal data of nine African centers and one Brazilian center demonstrated that CD4+TL 
count, weight-for-age and hemoglobin were the best predictors of risk for progression, with marginal effect of TLC. ${ }^{24}$

CD4+TL values at admission, categorized according to the WHO, were sensitive predictors of risk for disease progression in children older than 12 months. The authors could not find sensitive parameters for prediction of risk of progression in children younger than 12 months. This finding is supported by the recent therapeutic consensus that, recognizing the absence of sensitive prognostic markers in HIV-infected nursing infants, recommend immediate antiretroviral therapy in children younger than 12 months, regardless of CD4+TL values, plasma viral load and clinical manifestations. $8,25,26$

Plasma viral load was not a good marker of progression in the univariate analysis. It only showed significant difference in the oldest age group, and it was not able to differentiate progressors from non-progressors in none of the age groups in the multivariate analysis. Such finding is in accordance with data from the literature that report overlapping of levels of plasma viral load between patients with fast infection progression and classic progressors. ${ }^{4}$

The present study emphasizes the importance of nutritional status in the assessment of risk of disease progression in HIV-infected children older than 12 months.

\section{References}

1. Romanelli RM, Pinto J, Melo LJ, Vasconcelos MA, Pereira RM. Effectiveness of dual and triple antiretroviral therapy in the treatment of HIV-infected children. J Pediatr (Rio J). 2006;82: 260-5.

2. Candiani TM, Pinto J, Cardoso CA, Carvalho IR, Dias AC, Carneiro $M$, et al. Impact of highly active antiretroviral therapy (HAART) on the incidence of opportunistic infections, hospitalizations and mortality among children and adolescents living with HIV/AIDS in Belo Horizonte, Minas Gerais State, Brazil. Cad Saude Publica. 2007;23 Supl 3:S414-23.

3. Gona P, Van Dyke RB, Williams PL, Dankner WN, Chernoff MC, Nachman $S A$, et al. Incidence of opportunistic and other infections in HIV-infected children in the HAART era. JAMA. 2006; 296:292-300.

4. Shearer WT, Quinn TC, LaRussa P, Lew JF, Mofenson L, Almy S, et al. Viral load and disease progression in infants infected with human immunodeficiency virus type 1 . Women and Infants Transmission Study Group. N Engl J Med. 1997;336:1337-42.

5. Mofenson LM, Korelitz J, Meyer WA 3rd, Bethel J, Rich K, Pahwa $S$, et al. The relationship between serum human immunodeficiency virus type 1 (HIV-1) RNA level, CD4 lymphocyte percent, and long-term mortality risk in HIV-1-infected children. National Institute of Child Health and Human Development Intravenous Immunoglobulin Clinical Trial Study Group. J Infect Dis. 1997;175:1029-38.

6. Palumbo PE, Raskino C, Fiscus S, Pahwa S, Fowler MG, Spector $A S$, et al. Predictive value of quantitative plasma HIV RNA and CD4+ lymphocyte count in HIV-infected infants and children. JAMA. 1998;279:756-61.
7. Dunn D. HIV Pediatric Prognostic Markers Collaborative Study Group. Short-term risk of disease progression in HIV-1-infected children receiving no antiretroviral therapy or zidovudine monotherapy: a meta-analysis. Lancet. 2003;362:1605-11.

8. World Health Organization (WHO). Report of the WHO Technical Reference Group, Paediatric HIV/ART Care Guideline Group Meeting. Geneva, Switzerland, 10-11 April 2008. http:// www.who.int/hiv/topics/paediatric/en/ . Access: 08/01/09.

9. Brasil. Ministério da Saúde. Boletim Epidemiológico AIDS - Ano IV no 1 - julho a dezembro de 2006/janeiro a junho de 2007. Ano IV no $01-27^{a}$ a $52^{a}$ semanas epidemiológicas - julho a dezembro de $2006-01^{\text {a }}$ a $26^{a}$ semanas epidemiológicas - janeiro a junho de 2007. http://www.aids.gov.br/data/documents/ storedDocuments/ \%7BB8EF5DAF-23AE-4891-AD36-1903553A3174\%7D/ \%7B721527B6-FE7A-40DF-91C4-098BE8C704E0\%7D/ Boletim2007_internet090108.pdf. Access: 07/01/09.

10. HIV Pediatric Prognostic Markers Collaborative Study Group. Use of total lymphocyte count for informing when to start antiretroviral therapy in HIV-infected children: a meta- analysis of longitudinal data. Lancet. 2005;366:1868-74.

11. World Health Organization (WHO). Antiretroviral Therapy for HIV infection in infants and children in resource-limited settings: towards universal access: recommendations for a public health approach. Geneva: WHO; 2006. http://www.who.int/hiv/pub/ guidelines/paediatric020907.pdf . Access: 15/12/07.

12. Brasil. Ministério da Saúde. Secretaria de Vigilância em Saúde. Programa Nacional de DST e AIDS. Critérios de definição de casos de AIDS em adultos e crianças. Brasília: Ministério da Saúde; 2003. http://www.aids.gov.br/data/documents/ storedDocuments/

\%7BB8EF5DAF-23AE-4891-AD36-1903553A3174\%7D/ \%7B2A9F7D1C-093E-4A04-8380-84ED432964A5\%7D/ criterios.pdf . Access: 15/12/07.

13. Centers for Disease Control and Prevention - CDC. 1994 revised classification system for Human Immunodeficiency Virus infection in children less than 13 years of age. MMWR Recomm Rep. 1994;43(RR-12):1-10.

14. Sharland M, Blanche S, Castelli G, Ramos J, Gibb DM; PENTA Steering Committee. PENTA guidelines for use of antiretroviral therapy, 2004. HIV Med. 2004;5 Suppl 2:61-86.

15. Dean AG, Dean JA, Burton AH, Dicker RC. Epi Info: a general-purpose microcomputer program for public health information systems. Am J Prev Med. 1991; 7:178-82.

16. Lepage $P$, Msellati $P$, Hitimana DG, Bazubagira A, Van Goethem C, Simonon A, et al. Growth of human immunodeficiency type 1-infected and uninfected children: a prospective cohort study in Kigali, Rwanda, 1988 to 1993 . Pediatr Infect Dis J. 1996;15:479-85.

17. World Health Organization (WHO). Joint United Nations Programme on HIV/AIDS (UNAIDS). Epidemiological fact sheet on HIV and Aids. Core data on epidemiology and response Brazil. 2008 Update. http://www.who.int/globalatlas/ predefinedReports/EFS2008/full/EFS2008_BR.pdf . Access: 07/ 01/09.

18. Pinto JA. Marcadores prognósticos e diagnóstico precoce em uma coorte de crianças infectadas verticalmente pelo vírus da imunodeficiência humana tipo 1 (HIV-1) [dissertation]. Belo Horizonte, MG: Universidade Federal de Minas Gerais; 1999.

19. Pollack H, Glasberg H, Lee E, Nirenberg A, David R, Krasinski K, et al. Impaired early growth of infants perinatally infected with human immunodeficiency virus: correlation with viral load. J Pediatr. 1997;130:915-22. 
20. Miller TL, Easley KA, Zhang W, Orav EJ, Bier DM, Luder E, et al. Maternal and infant factors associated with failure to thrive in children with vertically transmitted human immunodeficiency virus-1 infection: the prospective, P2C2 human immunodeficiency virus multicenter study. Pediatrics. $2001 ; 108$ : 1287-96.

21. Chearskul S, Chotpitayasunondh T, Simonds RJ, Wanprapar N, Waranawat N, Punpanich W, et al. Survival, disease manifestations, and early predictors of disease progression among children with perinatal human immunodeficiency virus infection in Thailand. Pediatrics. 2002;110:e25.

22. Newell ML, Borja MC, Peckham C; European Collaborative Study. Height, weight, and growth in children born to mothers with HIV-1 infection in Europe. Pediatrics. 2003;111:e52-60.

23. Mofenson LM, Harris DR, Moye J, Bethel J, Korelitz J, Read JS, et al. Alternatives to HIV-1 RNA concentration and CD4+ to predict mortality in HIV-1-infected children in resource-poor settings. Lancet. 2003;362:1625-7.
24. Cross Continents Collaboration for Kids (3Cs4kids) Analysis and Writing Committee. Markers for predicting mortality in untreated HIV-infected children in resource-limited settings: a meta-analysis. AIDS. 2008;22:97-105.

25. USPHS Guidelines for the use of antiretroviral agents in pediatric HIV infection. July 29, 2008. http://aidsinfo.nih.gov/ contentfiles/PediatricGuidelines.pdf . Access: 19/01/09.

26. PENTA guidelines for the use of antiretroviral therapy in HIV paediatric infection - 2008 draft revision. http:// www.pentatrials.org/guide08.pdf . Access: 19/01/09.

Correspondence:

Jorge Andrade Pinto

Av. Alfredo Balena, 190/161

CEP 30130-100 - Belo Horizonte, MG, Brazil

Tel.: + 55 (31) 3409.9822

Fax: +55 (31) 3273.0422

E-mail: jpinto@medicina.ufmg.br 